\title{
Comparison between R.C.C and Steel Structures by Seismic Analysis
}

\author{
M.D. Vaseem and Dr.B.R. Patagundi
}

\begin{abstract}
In India use of steel is less because of its high cost. As the comparison of RC and steel structure is about its cost and its seismic analysis becomes important for bare frame which involves the parameters such as joint displacement, story forces, story stiffness, story drift, natural time period and base reaction. The seismic results that is static and dynamic analysis method under the provision of IS 1893-2002 using a zone-4 for 10 storied RC and steel structures is carried out by using ETABS 2015 software and the estimation is carried by MS Excel and slab design is carried by Mathcad prime software. In dynamic method it uses Response spectrum method. In the steel structure 10 story building is analyzed by use of ISMB450 for beams and ISWB600 with cover plate of $400 \times 20 \mathrm{~mm}$ for columns. $R C$ structure with steel columns at the periphery of the structure which uses ISWB600 including cover plate of $400 \times 20 \mathrm{~mm}$ and it is used at the 4 corners in another model.
\end{abstract}

Keywords--- Joint Displacement, Story Forces, Story Stiffness, Story Drift, Natural Time Period and Base Shear

\section{INTRODUCTION}

$\mathrm{M}$ OST of the structures are built by RCC in India, but steel structures are less in India as comparing to other countries due to its cost, but steel structures have better response during earthquake. For RCC structures beam columns are rigidly connected as concrete is a brittle and tough material but steel is a ductile and flexible material. For economy point of view RCC frames have less cost than that of steel frames.

The comparative study of RCC and steel bare frame includes its cost and the seismic results such as joint displacement, story forces, story drift, natural time period, story stiffness and base reaction. The comparison between static and dynamic analysis results can be compared, steel frames possess more displacement than that of RCC frames. Also other parameters like story forces, story stiffness, story drift and base shear have more values for steel frames than that of RCC frames. In most of the steel structures I section gives better advantageous compare to the other sections. Steel has more modulus of elasticity than that of concrete.

During the earthquake lateral movement of the structure takes place to resist those seismic forces in the structures static

M.D. Vaseem, M Tech (Structural Engineering), Student, S.G. Balekundri Institute of Technology, Belgaum, Karnataka, India. E-mail:vaseerec@gmail.com

Dr.B.R. Patagundi, Professor \& Head, Department of Civil Engineering, S.G Balekundri Institute of Technology, Belgaum, Karnataka, India. E-mail:brpatagundi@gmail.com

DOI:10.9756/BIJMMI.8170 method and dynamic method. In dynamic method response spectrum method is used and for gravity loading vertical movement of the structure takes place.

Also the composite construction essentially different materials are completely compatible and complementary to each other. Some of the structures with RCC frame with steel columns at the periphery have more seismic results than that of RCC frame with only steel columns at the corner. The structural engineering community has the ability to influence the direct consequences of these events by better understanding the seismic response of building structures and aiming to constantly improve their seismic design.

\section{A. Statement of the Problem}

The main focus of the present work is to analysis of multistorey RCC building and steel building and comparing its cost and seismic results for 10 story building. For this purpose frames are designed using ETABS 2015. Further the performance by static and dynamic method for the bare RCC and steel frames are carried out so that the seismic results such as joint displacement, story forces, story drift, natural time period and base shear values for static and dynamic analysis can be found out. Also one RCC frame with peripheral steel columns and RCC frame with steel columns at corners has been used.

\section{B. Objectives of the Study}

The main objectives of the present study are as follows.

1. Generation of 3D building model

2. To analyse the multi-storey RCC and steel building by static and dynamic analysis.

3. To perform lateral load analysis for different models.

4. To perform linear static analysis for RCC bare frame and Steel frame by using ETABS 2015

5. To perform dynamic analysis by response spectrum method for RCC bare frame and steel bare frame using ETABS 2015.

6. To obtain the seismic results such as joint displacement, story forces, story stiffness, story drift, natural time period and base shear for different building models.

7. To compare the joint displacement, story forces, story stiffness, story drift, natural time period and base shear of RCC bare frame and steel bare frame.

8. To compare the joint displacement, story forces, story stiffness, story drift, natural time period and base shear of RCC bare frame with steel columns at the periphery and RCC bare frame with steel columns at the 4 corners of the building. 


\section{MODELING AND ANALYSIS}

\section{A. General}

In earthquake resistant design, the structures are designed by two methods that is static method and dynamic method. In this study the RCC bare frame and steel bare frame are being analysed and modeled by static and dynamic i.e, by response spectrum method and the seismic results such as joint displacement, story drift, story forces, story stiffness, base shear and natural time period values are being compared also the cost is being compared. Also the composite frames are being modeled and analysed and results of those are being compared.

\section{B. Structural Modeling}

In the present study of RCC and steel structures the models are being analysed and modeled by static and dynamic methods, in dynamic method, the analysis can be done by the response spectrum method by using ETABS 2015 software. 10 story building of 4 models are being analysed and designed. The tables and graphs are being plotted by M.S excel. For steel bare frame the beams are used as ISMB 450 and the columns used are ISWB 600 with cover plate of $400 \times 20 \mathrm{~mm}$ which is attached on both sides that is top and bottom flanges of the I section.

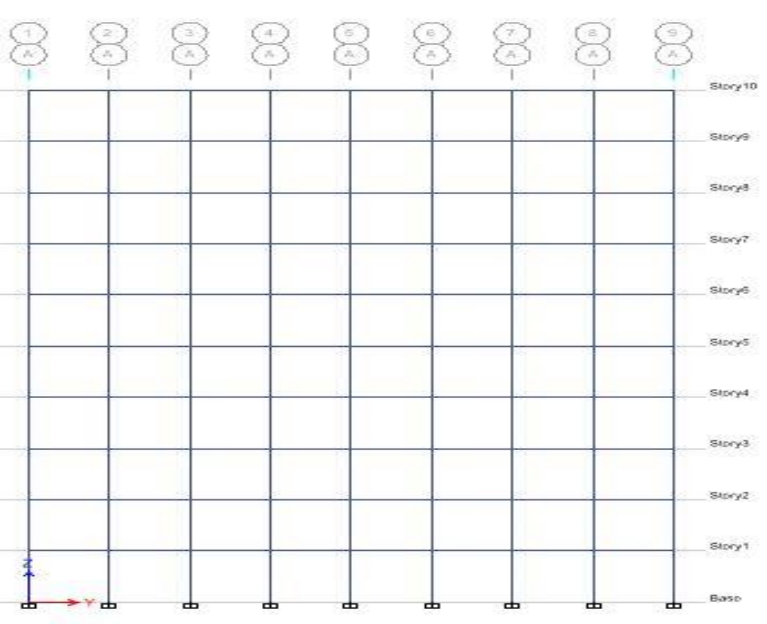

Figure 1: Elevation of RCC Frame

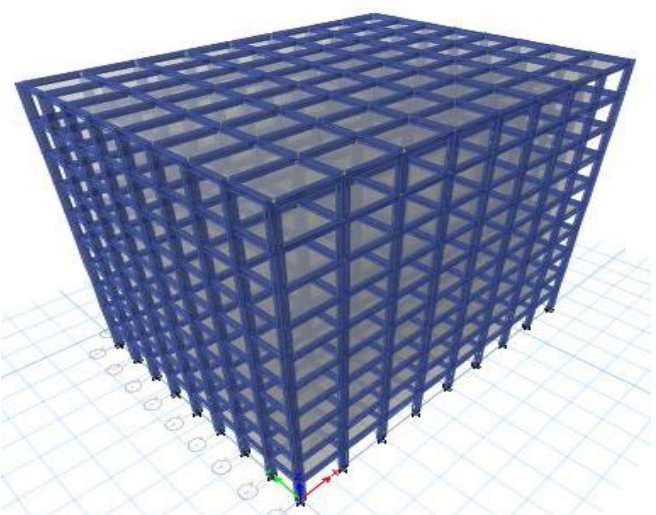

Figure 2: 3d View of RCC Frame

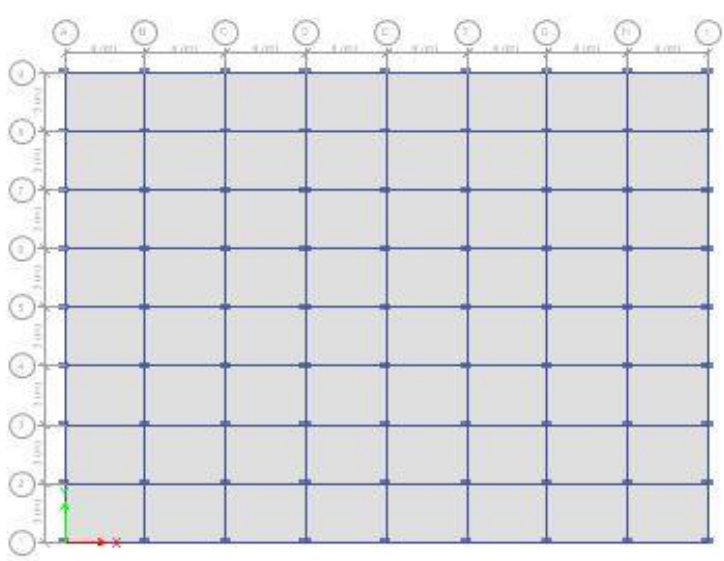

Figure 3: Plan of RCC Frame

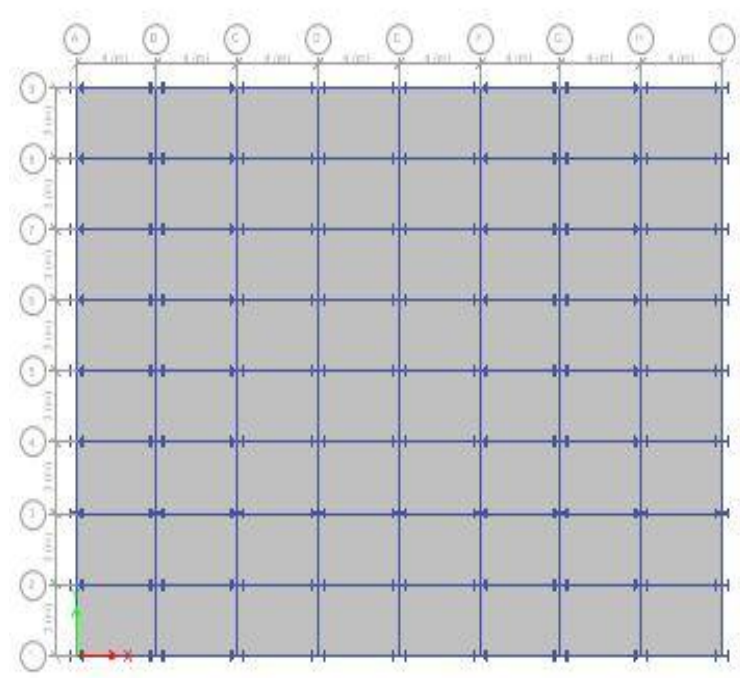

Figure 4: Plan of Steel Frame

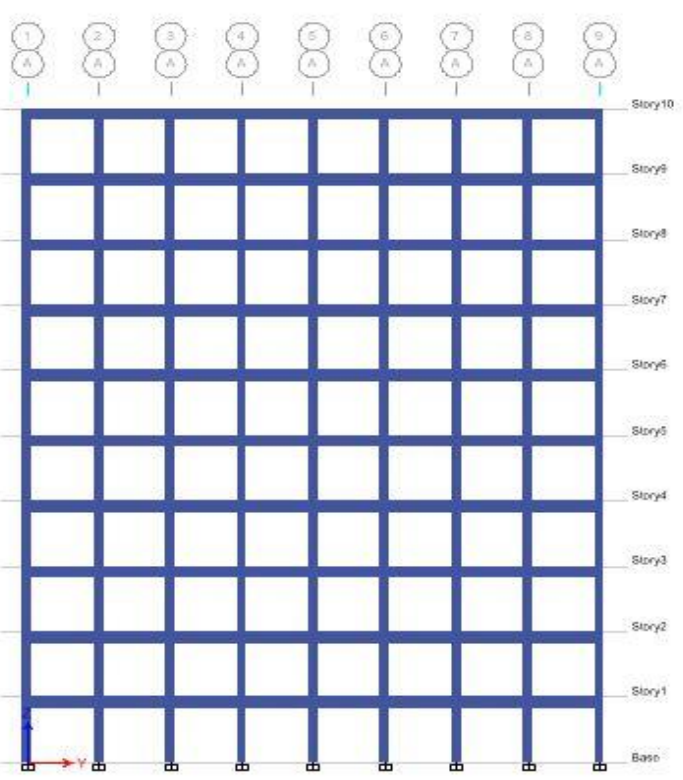

Figure 5: Elevation of Steel Frame 


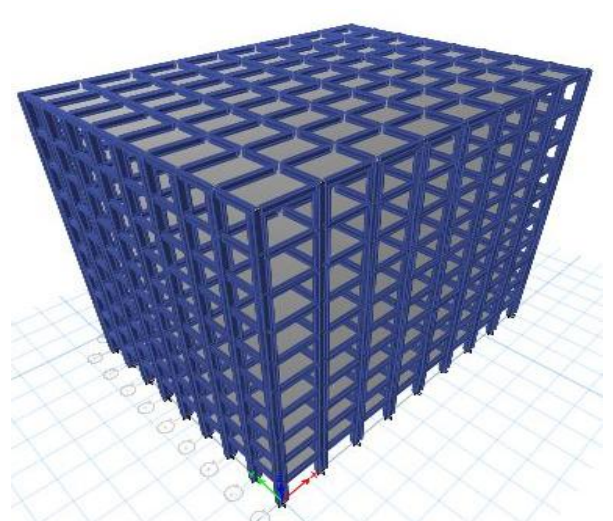

Figure 6: 3d View of Steel Frame

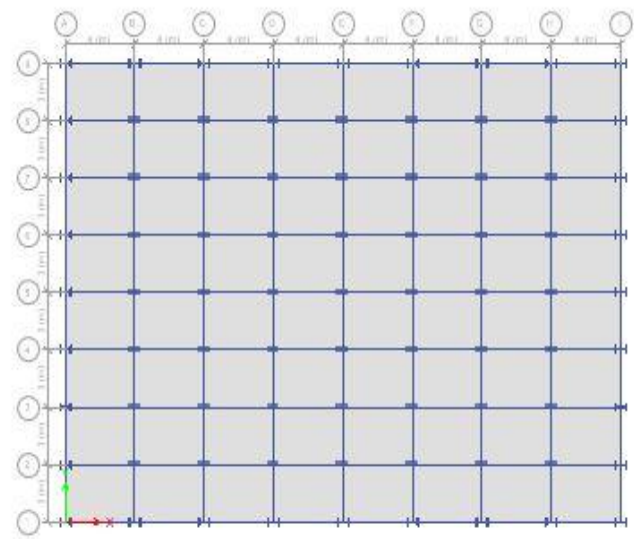

Figure 7: Plan of RCC Frame with Steel Columns at the Periphery

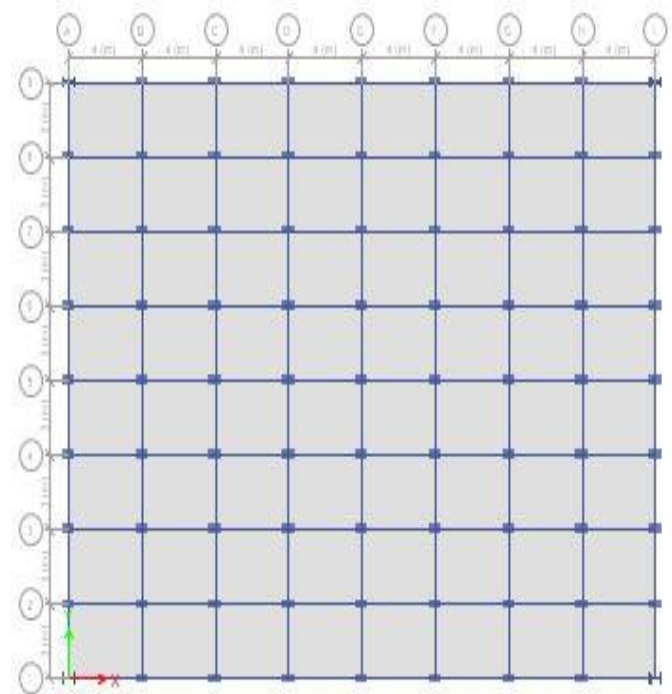

Figure 8: Plan of RCC Frame with Steel Columns at the Corners

\section{Details of Building}

Plan dimension

$=32 \times 24 \mathrm{~m}$

$=8$ bays in $\mathrm{X}$ direction and 8

bays in $\mathrm{Y}$ direction

Bays
Spacing of bays

Story height

Seismic zone

Type of soil

Details of Sections

1) For RCC Frame

Beam

Column

Slab

Diaphragm

Concrete

Steel

2) For Steel Frame

Beam

Column

Slab

Diaphragm

Concrete

Steel

3) RCC Frame with Steel Columns at the Periphery

Beam

Beam1

Column

Steel Column

Slab

Diaphragm

Concrete

Steel

4) RCC Frame with Steel Columns at the Corners

Beam

$=0.23 \times 0.70 \mathrm{~m}$

Column

Steel Column

$=0.35 \times 0.65 \mathrm{~m}$

$=$ ISWB600 with cover plate $400 \times 20 \mathrm{~mm}$

Slab

Diaphragm

$=0.125 \mathrm{~m}$

Concrete

$=$ Rigid

$=\mathrm{M} 25$

Steel

$=\mathrm{Fe} 250$ 


\section{Analysis of the Model}

The analysis can be done by Static and Dynamic methods. In dynamic by the response spectrum method. The seismic analysis can be done for RCC bare frame, steel bare frame, RCC bare frame with steel columns at the periphery and RCC bare frame with steel columns at the corners. By using response reduction factor as 5 also the importance factor as 1 , damping value of 5\% and zone-IV for all the four models by referring IS 1893 (Part-1) 2002. The seismic values such as joint displacement, story forces, story stiffness, story drift, natural time period and base shear can be determined for static and dynamic analysis.

Material properties considered for analysis

Grade of Concrete $=$ M25

Density of Concrete $=25 \mathrm{KN} / \mathrm{m} 3$

Density of Masonry Wall $=19 \mathrm{KN} / \mathrm{m} 3$

Grade of steel reinforcement $=$ HYSD 500

Grade of steel used for steel structure $=\mathrm{Fe} 250$

Details of loading

Live load $=3 \mathrm{KN} / \mathrm{m}^{2}$

Floor finish $=1.0 \mathrm{KN} / \mathrm{m}^{2}$

Wall load (for RCC frame) $=11.143 \mathrm{KN} / \mathrm{m}$

Wall load (for RC frame with steel columns at the periphery) $(0.23 \times(3-0.45) \times 19)=11.143 \mathrm{KN} / \mathrm{m}$

Wall load (for RCC frame with steel columns at the corners $)(0.23 \times(3-0.70) \times 19)=10.051 \mathrm{KN} / \mathrm{m}$

Table 1: Details of Seismic Loading

\begin{tabular}{|l|l|}
\hline Type of Structure & $\begin{array}{l}\text { Special Moment Resisting } \\
\text { Frame }\end{array}$ \\
\hline Damping Ratio & $5 \%$ \\
\hline Seismic Zone factor (Z) & 0.24 \\
\hline Importance Factor (I) & 1.0 \\
\hline $\begin{array}{l}\text { Response Reduction Factor } \\
\text { (R) }\end{array}$ & 5 \\
\hline
\end{tabular}

Load Combinations

1) For R.C.C Frame

$\mathrm{DL}+\mathrm{LL}+\mathrm{WL}+\mathrm{FF}=1.5$

$\mathrm{DL}+\mathrm{LL}+\mathrm{WL}+\mathrm{FF}+\mathrm{EQX}=1.2$

$\mathrm{DL}+\mathrm{LL}+\mathrm{WL}+\mathrm{FF}+\mathrm{EQY}=1.2$

$\mathrm{DL}+\mathrm{LL}+\mathrm{WL}+\mathrm{FF}+\mathrm{SPECX}=1.2$

$\mathrm{DL}+\mathrm{LL}+\mathrm{WL}+\mathrm{FF}+\mathrm{SPECY}=1.2$

2) For Steel Frame

$\mathrm{DL}+\mathrm{LL}+\mathrm{WL}+\mathrm{FF}=1.5$

$\mathrm{DL}+\mathrm{LL}+\mathrm{WL}+\mathrm{FF}+\mathrm{EQX}=1.3$

$\mathrm{DL}+\mathrm{LL}+\mathrm{WL}+\mathrm{FF}+\mathrm{EQY}=1.3$

$\mathrm{DL}+\mathrm{LL}+\mathrm{WL}+\mathrm{FF}+\mathrm{SPECX}=1.3$

$\mathrm{DL}+\mathrm{LL}+\mathrm{WL}+\mathrm{FF}+\mathrm{SPECY}=1.3$

\section{RESULTS AND DISCUSSION}

A. General

The results are presented in the form of Tables and Graphs for different types of building frame models such as the RCC and steel bare frame. Also the RCC frame with steel I sections at the periphery and RCC structure with steel columns at the corners. The parameters such as design base shear, natural period, joint displacement, story forces, story drift and story stiffness are considered and the cost and seismic results are being compared between RCC and steel frame also the seismic results are being compared between RCC frame with steel I sections at the periphery and RCC structure with steel columns at the corners.

\section{B. Seismic Results}

The following are the seismic results obtained from ETABS 2015 software.

\section{1) Joint Displacement}

The maximum joint displacement is obtained from the static and dynamic i.e, response spectrum method of analysis and comparison can be done between RCC and steel frames also between RCC frame with steel columns at the periphery and RCC frame with steel columns at the corners.

(a) For Static Analysis

Table 2: Comparison between RCC and Steel frame

\begin{tabular}{|l|l|l|l|l|}
\hline \multirow{3}{*}{ Story } & \multicolumn{2}{|l|}{ RCC Frame } & \multicolumn{2}{l|}{ Steel Frame } \\
\cline { 2 - 5 } & $U X$ & $U Y$ & $U X$ & $U Y$ \\
\cline { 2 - 5 } & $m m$ & $m m$ & $m m$ & $m m$ \\
\hline Story10 & 12.1 & 14.2 & 16.8 & 20.4 \\
\hline Story9 & 11.6 & 13.7 & 16 & 19.7 \\
\hline Story8 & 10.8 & 12.8 & 14.9 & 18.5 \\
\hline Story7 & 9.8 & 11.6 & 13.4 & 16.8 \\
\hline Story6 & 8.6 & 10.1 & 11.6 & 14.7 \\
\hline Story5 & 7.2 & 8.5 & 9.5 & 12.3 \\
\hline Story4 & 5.7 & 6.8 & 7.3 & 9.8 \\
\hline Story3 & 4.1 & 5.0 & 5 & 7.1 \\
\hline Story2 & 2.5 & 3.2 & 2.8 & 4.4 \\
\hline Story1 & 1.0 & 1.4 & 1 & 1.8 \\
\hline Base & 0.0 & 0.0 & 0.0 & 0.0 \\
\hline
\end{tabular}

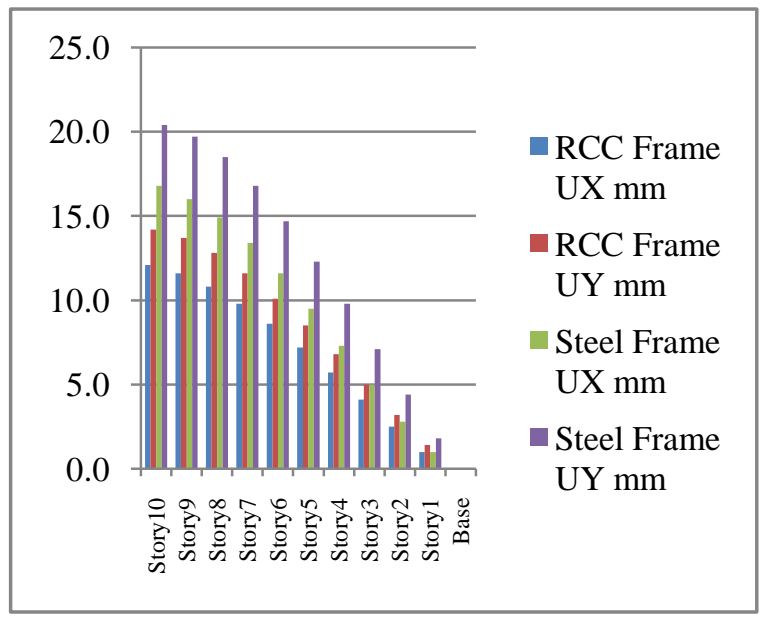

Figure 9: Comparison between RCC and Steel Frame 
Table 3: Comparison between RCC Frame with Steel Columns at the Periphery and RCC Frame with Steel Columns at the Corner

\begin{tabular}{|l|l|l|l|l|}
\hline \multirow{3}{*}{ Story } & \multicolumn{2}{|l|}{$\begin{array}{l}\text { RCC Frame with steel } \\
\text { Columns at periphery }\end{array}$} & \multicolumn{2}{l|}{$\begin{array}{l}\text { RC Frame with steel } \\
\text { Columns at corner }\end{array}$} \\
\cline { 2 - 5 } & UX & UY & UX & UY \\
\cline { 2 - 5 } & $\mathrm{mm}$ & $\mathrm{mm}$ & $\mathrm{mm}$ & $\mathrm{mm}$ \\
\hline Story10 & 14.5 & 16.5 & 11.1 & 14.7 \\
\hline Story9 & 13.8 & 15.9 & 10.7 & 14.1 \\
\hline Story8 & 12.7 & 14.8 & 10 & 13.2 \\
\hline Story7 & 11.3 & 13.3 & 9 & 11.9 \\
\hline Story6 & 9.7 & 11.5 & 7.9 & 10.4 \\
\hline Story5 & 7.9 & 9.5 & 6.6 & 8.8 \\
\hline Story4 & 5.9 & 7.4 & 5.2 & 7 \\
\hline Story3 & 3.9 & 5.2 & 3.8 & 5.2 \\
\hline Story2 & 2.1 & 3 & 2.4 & 3.4 \\
\hline Story1 & 0.7 & 1.1 & 1 & 1.5 \\
\hline Base & 0 & 0 & 0 & 0 \\
\hline
\end{tabular}

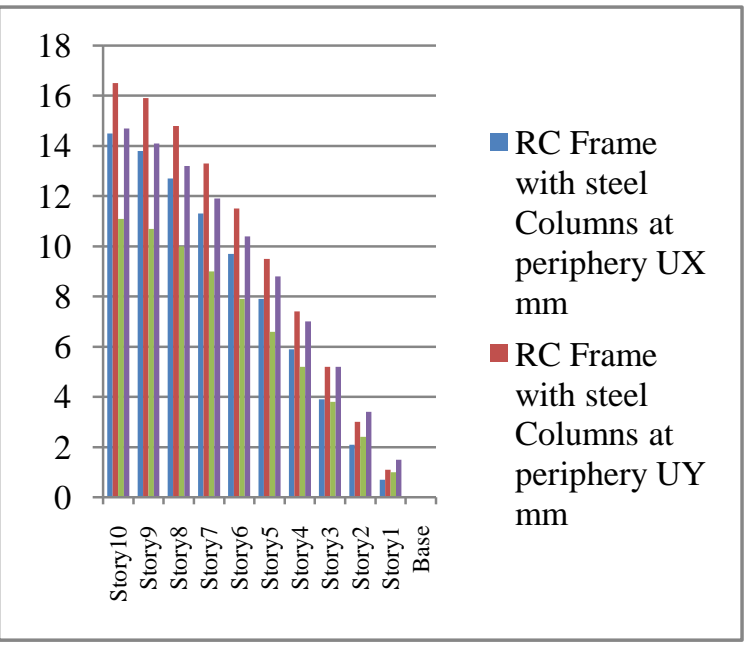

Figure 10: Comparison between RCC Frame with Steel Columns at the Periphery and RCC Frame with Steel Columns at the Corner

\section{(b) For Dynamic Analysis}

Table 4: Comparison between RCC and Steel Frame

\begin{tabular}{|l|l|l|l|l|}
\hline \multirow{3}{*}{ Story } & \multicolumn{2}{|l|}{ RCC Frame } & \multicolumn{2}{|c|}{ Steel Frame } \\
\cline { 2 - 5 } & $U X$ & $U Y$ & $U X$ & $U Y$ \\
\cline { 2 - 5 } & $m m$ & $m m$ & $m m$ & $m m$ \\
\hline Story10 & 9.2 & 10.3 & 12.5 & 14.5 \\
\hline Story9 & 8.9 & 10 & 12 & 14.1 \\
\hline Story8 & 8.4 & 9.5 & 11.3 & 13.4 \\
\hline Story7 & 7.8 & 8.8 & 10.3 & 12.4 \\
\hline Story6 & 6.9 & 7.9 & 9 & 11.1 \\
\hline Story5 & 5.9 & 6.8 & 7.6 & 9.6 \\
\hline Story4 & 4.8 & 5.6 & 5.9 & 7.9 \\
\hline Story3 & 3.6 & 4.2 & 4.2 & 6 \\
\hline Story2 & 2.2 & 2.8 & 2.4 & 3.9 \\
\hline Story1 & 0.9 & 1.2 & 0.8 & 1.6 \\
\hline Base & 0 & 0 & 0 & 0 \\
\hline
\end{tabular}

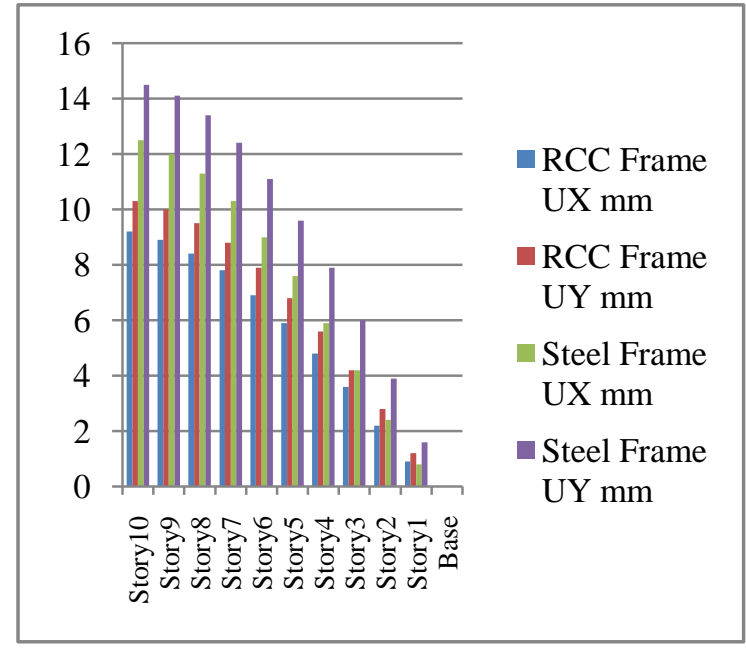

Figure 11: Comparison between RCC and Steel Frame

Table 5: Comparison between RCC frame with Steel Columns at the Periphery and RCC Frame with Steel Columns at the Corner

\begin{tabular}{|l|l|l|l|l|}
\hline \multirow{3}{*}{ Story } & \multicolumn{2}{|l|}{$\begin{array}{l}\text { RC Frame with steel } \\
\text { Columns at periphery }\end{array}$} & \multicolumn{2}{l|}{$\begin{array}{l}\text { RC Frame with steel } \\
\text { Columns at corner }\end{array}$} \\
\cline { 2 - 5 } & $U X$ & $U Y$ & $U X$ & UY \\
\cline { 2 - 5 } & $m m$ & $m m$ & $m m$ & $m m$ \\
\hline Story10 & 11.3 & 12.2 & 8.5 & 11 \\
\hline Story9 & 10.9 & 11.9 & 8.3 & 10.7 \\
\hline Story8 & 10.2 & 11.2 & 7.8 & 10.1 \\
\hline Story7 & 9.2 & 10.3 & 7.2 & 9.4 \\
\hline Story6 & 8 & 9.1 & 6.4 & 8.4 \\
\hline Story5 & 6.6 & 7.7 & 5.5 & 7.2 \\
\hline Story4 & 5 & 6.2 & 4.4 & 5.9 \\
\hline Story3 & 3.4 & 4.4 & 3.3 & 4.5 \\
\hline Story2 & 1.8 & 2.6 & 2.1 & 3 \\
\hline Story1 & 0.6 & 1 & 0.8 & 1.4 \\
\hline Base & 0 & 0 & 0 & 0 \\
\hline
\end{tabular}

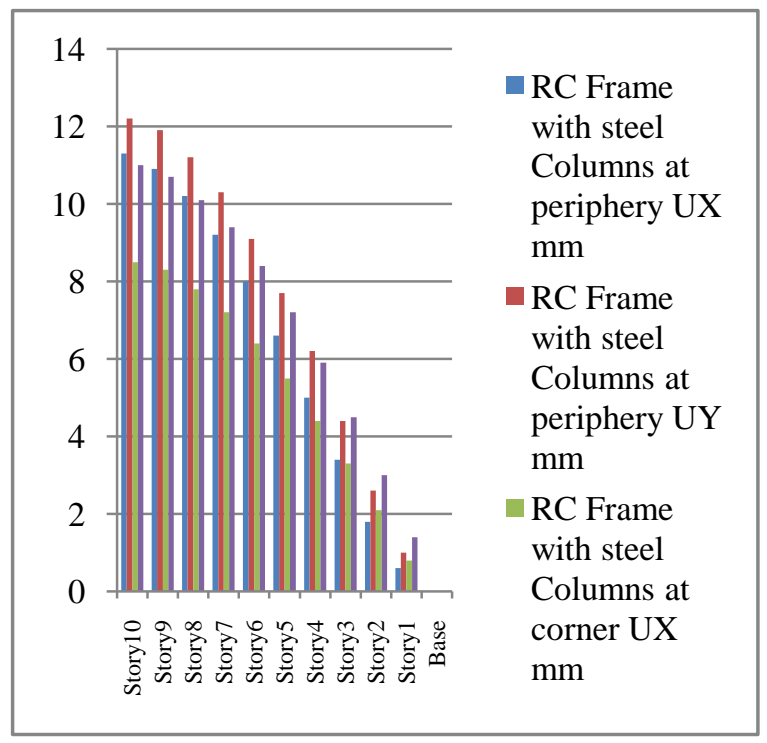

Figure 12: Comparison between RCC Frame with Steel Columns at the Periphery and RCC Frame with Steel Columns at the Corner 


\section{Design Results}

\section{R.C.C Frame}

1) Design of Beams: Size $=230 \times 450 \mathrm{~mm}$

All beams for all 10 stories are

Main bars: 2 No of bars $16 \mathrm{~mm}$ diameter at top and bottom.

Stirrups: (i) At corners $8 \mathrm{~mm}$ diameter $150 \mathrm{~mm} \mathrm{C} / \mathrm{C}$ $200 \mathrm{~mm} \mathrm{C} / \mathrm{C}$

(ii) At middle of the beam $8 \mathrm{~mm}$ diameter

2) Design of Columns: Size $=300 \times 450 \mathrm{~mm}$

All Columns for all 10 stories are

Main bars: $8 \mathrm{No}$ of bars $25 \mathrm{~mm}$ diameter

Stirrups: $8 \mathrm{~mm}$ diameter $300 \mathrm{~mm} \mathrm{C/C}$

3) Design of Slab: $125 \mathrm{~mm}$ Depth

All Slab for all 10 stories are

1) $\mathrm{R} / \mathrm{F}$ in +ve $\mathrm{X}$ direction $=8 \mathrm{~mm}$ diameter @ $300 \mathrm{~mm} \mathrm{C} / \mathrm{C}$

2) $\mathrm{R} / \mathrm{F}$ in +ve $\mathrm{Y}$ direction $=8 \mathrm{~mm}$ diameter @ $300 \mathrm{~mm} \mathrm{C} / \mathrm{C}$

3) $\mathrm{R} / \mathrm{F}$ in $-\mathrm{ve} \mathrm{X}$ direction $=8 \mathrm{~mm}$ diameter @ $300 \mathrm{~mm} \mathrm{C} / \mathrm{C}$

4) $\mathrm{R} / \mathrm{F}$ in $-\mathrm{ve} \mathrm{Y}$ direction $=8 \mathrm{~mm}$ diameter @ $300 \mathrm{~mm} \mathrm{C} / \mathrm{C}$

5) Distribution bars are also $8 \mathrm{~mm}$ diameter @ $300 \mathrm{~mm} \mathrm{C} / \mathrm{C}$

\section{Steel Frame}

1) Design of Beams: Size $=$ ISMB 450

2) Design of Columns: Size $=$ ISWB 600 with cover plate $(400 \times 20 \mathrm{~mm})$

3) Design of Slab: $125 \mathrm{~mm}$ Depth

All Slab for all 10 stories are

1) $\mathrm{R} / \mathrm{F}$ in +ve $\mathrm{X}$ direction $=8 \mathrm{~mm}$ diameter @ 300mm $\mathrm{C} / \mathrm{C}$

2) $\mathrm{R} / \mathrm{F}$ in $+\mathrm{ve} \mathrm{Y}$ direction $=8 \mathrm{~mm}$ diameter @ 300mm $\mathrm{C} / \mathrm{C}$

3) $\mathrm{R} / \mathrm{F}$ in $-\mathrm{ve} \mathrm{X}$ direction $=8 \mathrm{~mm}$ diameter @ 300mm $\mathrm{C} / \mathrm{C}$

4) $\mathrm{R} / \mathrm{F}$ in -ve $\mathrm{Y}$ direction $=8 \mathrm{~mm}$ diameter @ 300mm $\mathrm{C} / \mathrm{C}$

5) Distribution bars are also 8mm diameter @ 300mm $\mathrm{C} / \mathrm{C}$

D. Cost of the Building

Total cost of the R.C.C Frame = Rs. 14265804

Total cost of the Steel Frame = Rs. 45022788

Cost difference between R.C.C frame and Steel frame = Rs. 30756985

\section{CONCLUSION}

1) The seismic analysis by static and dynamic analysis for the R.C.C and steel frame can be compared and the seismic results can be obtained such as joint displacement, story forces, story stiffness, story drift, natural time period and base shear.

2) The cost difference between R.C.C and steel frame can be calculated.
3) The seismic analysis of the R.C.C frame with steel columns ISWB 600 with cover plate at the periphery and R.C.C frame with steel columns ISWB 600 with cover plate at the corners can be analysed and compared and the seismic results can be obtained such as joint displacement, story forces, story stiffness, story drift, natural time period and base shear.

4) The graphs can be plotted for the respective seismic results.

5) Steel frame is more costlier than R.C.C frame.

6) The seismic results are more for Steel frame than the R.C.C frame.

\section{REFERENCES}

[1]. P. Sangave, M.N. Madur, M.S. Waghmare, M.R. Shete, M.V. Mankondi and M.V. Gundla, "Comparative Study of Analysis and Design of RC and Steel Structures", International Journal of Science \& Engineering Research, Vol. 6, No. 2, 2015.

[2]. M.S. Kumawat and L.G. Kalurkar, "Static \& dynamic analysis of multistory building using composite structure. International Journal of Research in Engineering and Technology, Vol. 3, 2014.

[3]. S.K. Adhikari, Dr.K. Rajasekhar, "Comparative Static and Dynamic Study on Seismic Analysis of Uniform and non uniform column sections in a Building", International Journal of Innovative Research in Science, Engineering and Technology, (An ISO 3297:2007 Certified Organization), Vol. 4, No. 8, 2015.

[4]. M.R. Sultan, "Dynamic Analysis of Multi-storey Building for different Shapes", International Journal of Innovative Research in Advanced Engineering, ISSN:2349-2163, Vol. 2, No. 8, 2015.

[5]. S.A. Wagh, Dr.U.P. Waghe, "Comparative study of R.C.C and Steel Concrete Composite Structures", International Journal of Engineering Research and Applications, (ISSN:2248-9622, Vol. 4, No. 4, Pp. 369376.

[6]. Arvind Reddy and R.J. Fernandes, "Seismic Analysis of RC regular and irregular frame structures", International Research Journal of Engineering and Technology,(Volume: 02 Issue:05/ Aug-2015).

[7]. P. S. Gaikwad and K.K. Tolani, "Review Paper on Dynamic Analysis of Building", International Journal of Current Engineering and Technology, (O2015INPRESSCO®.

[8]. D.R. Panchal and P.M. Marathe, "Analysis, Design and Modelling of the Seismic Behaviour of R.C.C, Steel \& Composite (G+30 Story) Building", Computational Methods in Structural Dynamics and Earthquake Engineering, Kos Island, Greece, 12-14, 2013.

[9]. Prof. V.S. Sawant, Prof. Y.R. Suryawanshi, A.V. Renavikar, "Survey on Comparison of Steel and Concrete Composite Beam Column Connections", International Journal of Innovative Research in Science, Engineering and Technology, Vol.4, No. 4, 2015.

[10]. S. Mahmoud and W. Abdallah, "Response Analysis of Multi-storey RC Buildings under Equivalent Static and Dynamic loads according to Egyptian code", International Journal of Civil and Structural Engineering Research, Vol. 2, No. 1, Pp. 79-88, 2014.

[11]. E. Pavan Kumar, A. Naresh, M. Nagajyothi and M. Rajasekhar, "Earthquake Analysis of Multi storied Residential Building-A Case study", International Journal of Engineering Research and Applications, Vol. 4, No. 11, Pp. 59-64, 2014.

[12]. M. Sharma, Dr.S. Maru, "Dynamic Analysis of Multistoried Regular Building", ISOR Journal of Mechanical and Civil Engineering (IOSRJMCE), Vol.11, No. 1, Pp. 37-42, 2014.

[13]. B. Bagheri, E. Salimi Firoozabad, and M. Reza Yahyaei, "Comparative Study of the Static and Dynamic Analysis of Multi-Storey Irregular Building", International Journal of Civil, Environmental, Structural, Construction and Architectural Engineering, Vol. 6, No. 11, 2012.

[14]. Niniwin and Kyaw Lin Htat, "Comparative Study of Static and Dynamic Analysis of Irregular reinforced concrete Building due to Earthquake", International Journal Scientific, Engineering and Technology Research, ISSN 2319-8885, Vol. 3, No. 7, 2014. 


\section{IS Codes}

[15]. IS 456-2000 (For Plain and Reinforced Concrete-Code of practice)

[16]. IS 1893-2002 (Part-1) (For Earthquake Resistance Design of Structures)

[17]. IS 875(Part 1): 1987 (Dead Loads - Unit Weight of Building Material and Stored Material)

[18]. IS 875(Part 2): 1987 (Imposed Loads) 